\title{
Positive outcomes of phosphodiesterase type 5 inhibitor on histopathologic and biochemical changes induced by ureteral obstruction
}

\author{
(D) Sibel Köktürk1 \\ (iD)Erdal Benli² \\ iD Ali Ayyıldiz \\ iD Selma Cirrik \\ (iD) Yeliz Çetinkol ${ }^{4}$ \\ Dema Nur Ayyıldı ${ }^{5}$ \\ (iD) Tevfik Noyan ${ }^{5}$
}

1. Department of Histology and Embryology, Faculty of Medicine, Istanbul University, Istanbul, Turkey 2. Department of Urology, Faculty of Medicine, Ordu University, Ordu, Turkey 3. Department of Physiology, Faculty of Medicine, Ordu University, Ordu, Turkey 4. Department of Medical Microbiology, Faculty of Medicine, Ordu University, Ordu, Turkey

5. Department of Biochemistry, Ordu University Faculty of Medicine, Ordu, Turkey

http://dx.doi.org/10.1590/1806-9282.65.3.388

\section{SUMMARY}

OBJECTIVES: We examined the effects of tadalafil, one of the phosphodiesterase type 5 (PDE5) inhibitors, in a rat model of with partial and complete unilateral ureteral obstruction (UUO).

METHODS: The rats were divided into 5 groups: sham ( $n=6)$, partial unilateral ureteral obstruction (PUUO, $n=6)$, PUUO with tadalafil treatment (PUUO+T; Cialis, $10 \mathrm{mg} / 72 \mathrm{~h}$, intragastric; Lilly, Indianapolis, Indiana, USA), complete unilateral ureteral obstruction (CUUO, $n=6)$, and CUUO with tadalafil treatment $(C \cup \cup O+T)$.

RESULTS: Fifteen days after the UUO, the ureter presented changes in the layers of urothelium and significant infiltration of inflammatory cells in the PUUO and CUUO groups. Compared with the sham, PUUO and CUUO groups had severe increased inflammatory cell infiltration. The urothelial epithelium exhibited cell degeneration and loss because of the swollen, atrophic, and denuded epithelial cells in the PUUO and CUUO groups. In the PUUO+T and CUUO+T groups, the urothelium revealed less epithelial cell degeneration and loss.

The expressions of $\alpha$-smooth muscle actin ( $\alpha-S M A)$ and transforming growth factor- $\beta$ (TGF- $\beta$ ) exhibited up-regulation in the PUUO and CUUO groups. The expression of TGF- $\beta$ decreased positively correlated with that of $\alpha-S M A$ in the tadalafil therapy groups, PUUO+T and CUUO+T.

CONCLUSION: The phosphodiesterase type 5 inhibitor's tadalafil reduced expressions of $\alpha-S M A$ and TGF- $\beta$ in the obstructed ureters, measured by biochemical examinations. In addition, tadalafil decreased urothelium degeneration due to the decreased epithelial cell loss and inflammatory cell infiltration. Our results show that tadalafil prevents or slows down the onset of ureter inflammation and urothelial degeneration in rats with UUO.

KEYWORDS Phosphodiesterase type 5 inhibitor, Tadalafil, obstruction, histopathologic and biochemical

DATE OF SUBMISSION: 30-Aug-2018

DATE OF ACCEPTANCE: 02-Oct-2018

CORRESPONDING AUTHOR: Sibel Köktürk

Ordu University, Faculty of Medicine, Department of Histology and Embryology, 52200, Ordu, Turkey

Ordu - 52200

E-mail: sibelkokturk1@gmail.com 


\section{INTRODUCTION}

Ureteric obstruction, one of the most common diseases in the urinary tract, can lead to obstructive uropathy ${ }^{1}$. During ureteric obstruction, the dilated ureter presents hypertrophy of the ureteric smooth muscle and proliferation of connective tissues ${ }^{2,3}$.

UUO, a commonly used experimental model of chronic kidney injury is characterized by tubular atrophy, inflammation, and interstitial fibrosis ${ }^{4,5}$. Unilateral ureteral obstruction causes significant tubulointerstitial fibrosis in the kidney. Ureteric obstruction, both complete and incomplete, can lead to severe ureteric injury ${ }^{1}$. Nevertheless, the degeneration, proliferation, and regeneration of the urethelial layer in the obstructed ureters have not been well documented and fully understood ${ }^{6}$.

Renal fibrosis is a common feature of various kidney diseases leading to end-stage renal failure ${ }^{7}$. Epithelial-to-mesenchymal transition contributes to renal fibrosis in chronic kidney disease ${ }^{8}$. Transforming growth factor- $\beta$ (TGF- $\beta$ ), one of the profibrotic growth factors produced by epithelial cells and macrophages, plays a crucial role in the pathogenesis of tissue fibrosis ${ }^{9,10}$.

The myofibroblasts are major contributors to the increased extracellular matrix deposition seen in kidney fibrosis ${ }^{11}$. Fibrosis is characterized by the accumulation of myofibroblasts defined by the expression of $\alpha$-smooth muscle actin ( $\alpha$-SMA). Fibroblast differentiation to the myofibroblast phenotype is associated with $\alpha$-SMA expression and regulated by cytokines. The TGF- $\beta$ can stimulate and inhibit myofibroblast differentiation ${ }^{12}$. Many studies demonstrate that renal tubular cells can be converted to myofibroblasts during epithelial-mesenchymal transition stimulated by TGF- $\beta^{13}$. The TGF- $\beta$ promoted $\alpha$-SMA expression or myofibroblast differentiation ${ }^{12}$.

Tadalafil is one of the most commonly used phosphodiesterase type 5 (PDE5) inhibitors 14 . It has a markedly different molecular structure than sildenafil and vardenafil, and these structural differences have implications for the selectivity and pharmacokinetics of the three PDE5 inhibitors 15. In 2011, the first experimental study to use tadalafil in the kidney during ischemia was published, with a finding of a decrease in leukocyte infiltration in animals that used this medication 16. However, the effect of tadalafil on inflammation and the urothelial layer in the ureter has not been studied.

We examined the effects of tadalafil one from
PDE5 inhibitors in a rat model of partial and complete unilateral ureteral obstruction in the ureter. The histopathologic and biochemical changes in obstructed ureters were determined using Hematoxyline and Eosin staining and tissue analysis of $\alpha$-SMA and TGF- $\beta$ in Sprague-Dawley rats.

\section{METHODS}

The study comprised male Sprague-Dawley rats (body weight 250-300 g). All experimental protocols followed the principles of the Declaration of Helsinki and received full approval from the Animal Ethical Committee of the Ordu University, Turkey.

The rats were divided into five groups, sham-operated $(n=6)$; partial unilateral ureteral obstruction (PUUO, n=6); and PUUO with tadalafil treatment (PUUO+T; Cialis, 10 mg/72 h, intragastric; Lilly, Indianapolis, Indiana, USA); complete unilateral ureteral obstruction (CUUO, n=6); and CUUO with tadalafil treatment (CUUO+T).

The unilateral ligation of the left ureters was performed in the ureteral obstruction groups, as described previously ${ }^{1}$. Briefly, under general anesthesia (ketamine, $50 \mathrm{mg} / \mathrm{kg}$, im), laparotomy was performed on the ureter. The PUUO and PUUO+T groups were then received a 24-gauge intravenous catheter into the proximal ureter, and the ureter and catheter around the ureter were connected using a 4-0 silk suture. The remainder ureters were subsequently narrowed by placing a ligature over the catheter. After partial ureteral obstruction, the abdominal incision was closed. In the CUUO and CUUO+T groups, the left ureter was ligated with silk at two points and cut between the ligatures. After ureteric ligation, the surgical incision was closed.

The sham rats underwent the same procedure, except that the left ureters were not ligated. The rats were killed for examination 15 days after the ligation. The ureters were removed and divided; some portions were stored at $-80{ }^{\circ} \mathrm{C}$ for tissue analysis, while others were fixed in $4 \%$ paraformaldehyde. Following fixation, the tissues were embedded in paraffin, and about $5 \mu \mathrm{m}$ sections were cut for histopathologic examinations.

\section{HISTOPATHOLOGIC EXAMINATION}

The proximal portion of the ureter was prepared for light microscopy by staining with hematoxylin 

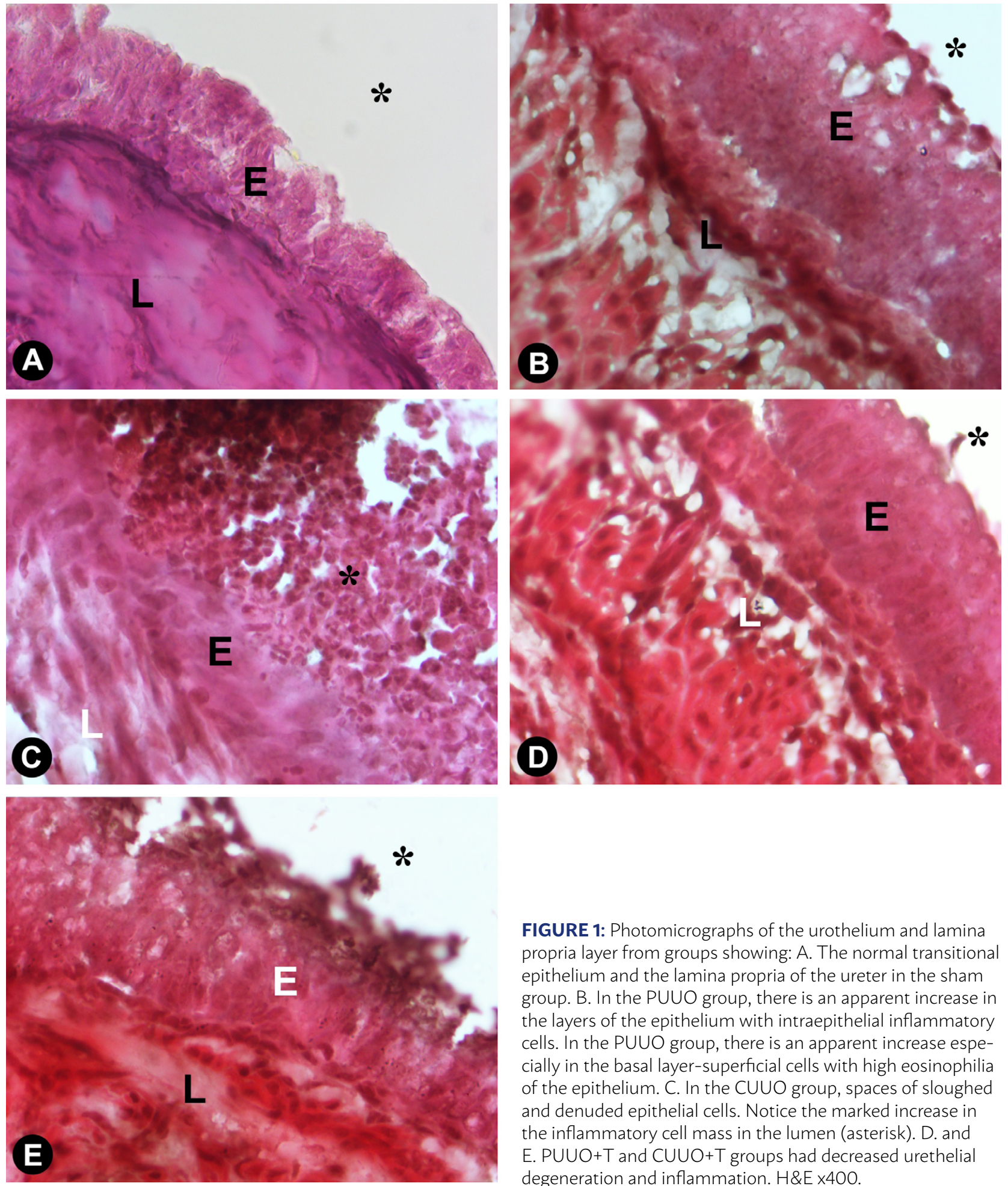

FIGURE 1: Photomicrographs of the urothelium and lamina propria layer from groups showing: A. The normal transitional epithelium and the lamina propria of the ureter in the sham group. B. In the PUUO group, there is an apparent increase in the layers of the epithelium with intraepithelial inflammatory cells. In the PUUO group, there is an apparent increase especially in the basal layer-superficial cells with high eosinophilia of the epithelium. C. In the CUUO group, spaces of sloughed and denuded epithelial cells. Notice the marked increase in the inflammatory cell mass in the lumen (asterisk). D. and E. PUUO+T and CUUO+T groups had decreased urethelial degeneration and inflammation. H\&E x400.

and eosin (H\&E) for morphological evaluations.

The loss of epithelial cells was assessed by the total number of urothelial nuclei in a selected field (magnification $\mathrm{x} 400$ ). The mean value was calculated from randomly 2 selected fields per ureter in the 6 animals for each group ${ }^{17}$.

The ureter sections were acquired systematically and sampled randomly. They were scored de-

pending on the quantity of the inflammatory cell infiltration as follows: score 0: no cells; score 1: a few cells; score 2: many cells; and score 3 : many cells in the in the ureter ${ }^{18}$.

Finally, images of the stained sections were captured with a Leica DFC295 HD color digital camera mounted on a Leica DM2500 microscope and stored as Tagged Image File Format images. 

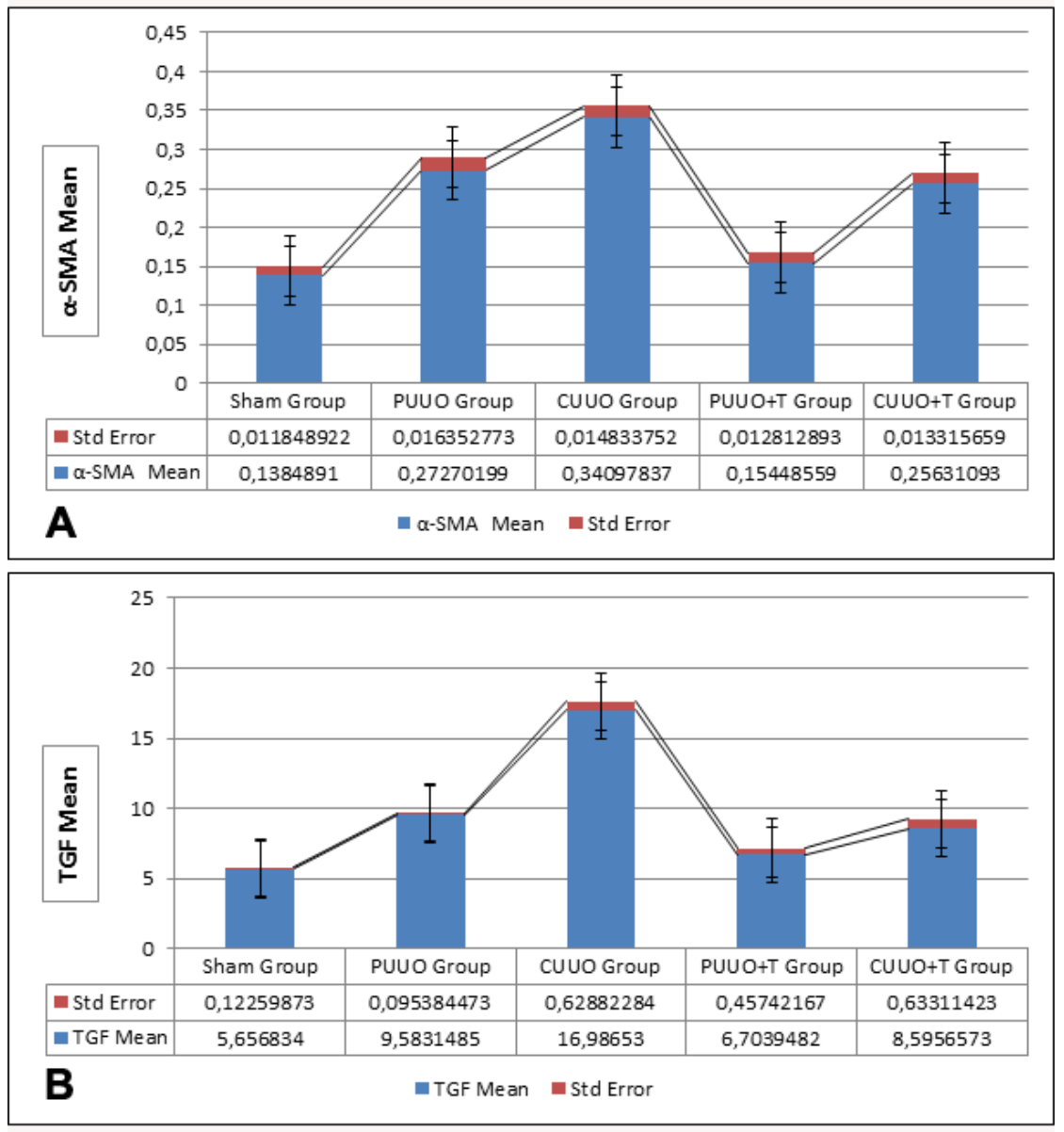

FIGURE 2: A. Tissue analysis of $\alpha$ -smooth muscle $(\alpha-S M A)$ and $B$. Transforming growth factor $-\beta$ (TGF- $\beta$ ) expressions in ureters using ELISA. The $\alpha$-SMA and TGF- $\beta$ expression levels were up-regulated in the PUUO and CUUO groups; however, they were down-regulated in the PUUO+T and CUUO+T groups ( ${ }^{*} \mathrm{P}<0.0001$ versus control).

\section{BIOCHEMICAL EXAMINATIONS}

Tissue analyzes of $\alpha$-SMA and TGF- $\beta$ were performed in the ureter tissue homogenates (Witeg Labortechnik GmgH, WiseTis HG-15D Homogenizer). After two freeze-thaw cycles, the homogenates were centrifuged for 5 minutes at $5000 \mathrm{~g}\left(2-8{ }^{\circ} \mathrm{C}\right)$. In the supernates, $\alpha$-SMA and TGF- $\beta$ levels were assayed using appropriate enzyme-linked immunosorbent assay (ELISA) kits (Cusabio CSB-E14027r and Boster EK0514, respectively). The analyses were performed according to the product instruction and read using an absorbance microplate reader (BioTek, ELx800). The concentration of total proteins in the homogenates was determined by the Bradford method using Coomassie reagent (Thermo scientific; 23200) and bovine serum albumin as standard.

\section{Statistics}

Data were expressed as mean \pm standard error of the mean (SEM) and analyzed using analysis of variance (ANOVA) for comparison among multiple groups using the Tukey post-test analysis for comparison and KaleidaGraph 4.0 software. All p-values lower than 0.05 were considered to be statistically significant.

\section{RESULTS}

The histopathologic examination using H\&E staining showed normal urothelium and lamina propria layer in the ureters of the sham group. The urothelium of the ureter was histologically normal in the sham group. The normal ureter was lined by three to four cells deep transitional epithelium and no inflammatory cell infiltration (score 0 , Figure 1A).

The PUUO group exhibited inflammatory cell infiltration (score 2), severe epithelial atrophy, and swelling of the epithelial cells. In the PUUO group, the epithelium was thickened and lined by three to eight-layered cells $(\mathrm{P}<0.0001)$. In the PUUO group, vacuoles appeared in the squamous epithelial cells (Figure 1B).

In the CUUO group, the urothelium was partially or completely denuded with a loss of epithelial cells. The epithelial cells had irregularly shaped and darkly stained pyknotic nuclei. In the CUUO group, the epithelium became thinner, down to 2-4 layers $(\mathrm{P}<$ 
0.0001), and the cells were exposed to the ureteral lumen. The CUUO group exhibited epithelial hemorrhage as well as infiltration of inflammatory cells (score 3) into the urothelium and lamina propria layer. The urothelium, interstitial spaces, and ureteral lumen were filled with large macrophages (Figure 1C).

The PUUO+T group exhibited attenuated inflammatory cell infiltration (score 1) and less swelling of the epithelial cells compared with the PUUO group (P $<0.0001$, Figure 1D). The inflammation was higher in the CUUO+T group than in the PUUO+T group. In the CUUO+T group, the inflammation was less significant than the CUUO group ((score 2, Figure 1D).

The PUUO and CUUO groups exhibited up-regulation of $\alpha$-SMA and TGF- $\beta(\mathrm{P}<0.0001)$. The PUUO+T and CUUO+T groups exhibited down-regulation of $\alpha$-SMA and TGF- $\beta(\mathrm{P}<0.0001)$. There was no significant difference between the expressions of the $\alpha$-SMA and TGF- $\beta$ in the control, PUUO+T and CU$\mathrm{UO}+\mathrm{T}$ groups (Figure $2 \mathrm{~A}$ and $\mathrm{B}$ ).

\section{DISCUSSION}

Ureteric obstruction is one of the most common problems faced by urologists ${ }^{19,20}$. Ureteric obstruction, both complete and partial, can lead to severe ureteric injury ${ }^{1}$. Ureteric obstruction causes ureteric injury as well as renal hemodynamic and metabolic changes, leading to tubular injury and renal inflammation, characterized by macrophage infiltration. Infiltration of macrophages, causing a release of cytokines to induce tubular cell apoptosis, activate and increase proliferation of fibroblasts ${ }^{5,21}$. Upon recruitment and activation, macrophages produce various pro-inflammatory cytokines, such as TGF- $\beta$, which in turn promote expression of adhesion molecules and contribute to further recruitment of circulating inflammatory cells ${ }^{21,22}$. The present study demonstrated that there was an increase in inflammatory cell infiltration and degenerative changes of epithelial cells in the obstructed ureters. These results agree with the clinical changes during hydroureter ${ }^{23}$ and those of other animal studies ${ }^{2,3}$.
Several studies have shown that TGF- $\beta$ stimulates $\alpha$-SMA expression and tissue fibrosis in both experimental and human kidney disease. The blocking of TGF- $\beta$ protects mice with diabetes from renal dysfunction, especially glomerular hypertrophy and fibrosis ${ }^{9,24}$. In the present study, the tadalafil therapy groups exhibited decreased inflammatory cell infiltration in the ureters. Our results also indicate that partial and complete unilateral ureteral obstruction led to a marked the up-regulation of $\alpha$-SMA and TGF- $\beta$, whereas the tadalafil treatment moderately improved these effects in the ureters.

The first experimental study with tadalafil in ischemia was performed in cardiomyocytes ${ }^{25}$, in which the use of tadalafil prior to coronary occlusion in rats led to improved endothelial function and decreased ischemic area in myocardial infarction. Several clinical studies have shown favorable safety and efficacy profiles of tadalafil for men with erectile dysfunction and diabetes ${ }^{26}$, hypertension, or heart disease ${ }^{27,28}$. The present study showed that tadalafil therapy decreases atrophy, vacuoles, swelling, and pyknotic nuclei in epithelial cells.

\section{CONCLUSIONS}

Our results suggest that tadalafil merits further exploration as a therapeutic agent in the prevention and treatment of ureteral obstruction disease. T ameliorate by the tadalafil, one of the PDE5 inhibitors, can have positive outcomes on ureteral obstruction. More investigation needs to be carried out, but the early evidence is promising for different doses and combination therapy.

\section{Funding}

This study was supported by the Education and Research Foundation of Faculty of Medicine, Ordu University, No. AR-1362.

\section{Conflict of Interest}

The authors declared no potential conflicts of interest concerning the research, authorship, and/or publication of this article.

\section{RESUMO}

OBJETIVOS: Examinamos os efeitos do tadalafil em um dos inibidores da fosfodiesterase tipo 5 (PDE5) em um modelo de rato com obstrução ureteral unilateral parcial e completa (UUO).

MÉTODOS: Os ratos foram divididos em cinco grupos: sham $(n=6)$, obstrução ureteral unilateral parcial (PUUO, $n=6)$, PUUO com tadalafil (PUUO T; Cialis, 10 mg/72 h, intragástrica; Lilly, Indianapolis, Indiana, EUA), completa obstrução ureteral unilateral (CUUO, $n=6)$ e CUUO com tratamento com tadalafil (CUUO T). 
RESULTADOS: Quinze dias após a UUO, o ureter apresentou alterações nas camadas de urotélio e infiltração significativa de células inflamatórias nos grupos PUUO e CUUO. Em comparação com os grupos sham, PUUO e CUUO, houve um aumento grave da infitração de células inflamatórias. O epitélio urotelial exibiu degeneração e perda celular devido às células epiteliais inchadas, atróficas e desnudas nos grupos PUUO e CUUO. Nos grupos PUUO T e CUUO T, o urotélio revelou menor degeneração e perda de células epiteliais. Nós mostramos que a expressão da actina do músculo liso- $\alpha(\alpha-S M A)$ e do fator de crescimento transformador- $\beta$ (TGF- $\beta$ ) foram exibidas como sub-regulação nos grupos PUUO e CUUO. A expressão do TGF- $\beta$ foi diminuída positivamente correlacionada com a da $\alpha-S M A$ nos grupos de terapia com tadalafil, PUUO T e CUUO T.

CONCLUSÃO: O tadalafil do inibidor da fosfodiesterase tipo 5 reduziu as expressões $\alpha$-SMA e TGF- $\beta$ nos ureteres obstruídos, medidos por exames bioquímicos. Além disso, o tadalafil diminuiu a degeneração do urotélio devido à diminuição da perda de células epiteliais e da infiltração de células inflamatórias. Nossos resultados mostram que o tadalafil previne ou retarda o início da inflamação do ureter e degeneração urotelial em ratos com UUO.

PALAVRAS-CHAVE: Inibidor da fosfodiesterase tipo 5. Tadalafil. Obstrução. Histopatologia e Bioquímica

\section{REFERENCES}

1. Chuang $\mathrm{YH}$, Chuang WL, Liu KM, Chen SS, Huang $\mathrm{CH}$. Tissue damage and regeneration of ureteric smooth muscle in rats with obstructive uropathy. Br J Urol. 1998; 82: 261-6.

2. Cheng EY, Maizels M, Chou P, Hartanto V, Shapiro E. Response of the newborn ureteropelvic junction complex to induced and later reversed partial ureteral obstruction in the rabbit model. . Urol. 1993; 150: 782-9.

3. Harada T, Issa MM, Kigure T, Tsuchida S. Ureteral compliance and histology in partial obstruction in a canine model. J Urol. 1992; 148: 1274-8.

4. Stefanska A, Eng D, Kaverina $\mathrm{N}$ et al. Cells of renin lineage express hypoxia inducible factor 2alpha following experimental ureteral obstruction. BMC Nephrol. 2016; 17: 5.

5. Ucero AC, Benito-Martin A, Izquierdo MC et al. Unilateral ureteral obstruction: beyond obstruction. Int Urol Nephrol. 2014; 46: 765-76.

6. Bianchi D, Vespasiani G, Bove P. Acute kidney injury due to bilateral ureteral obstruction in children. World / Nephrol. 2014; 3: 182-92.

7. Okada H, Ban S, Nagao S, Takahashi H, Suzuki H, Neilson EG. Progressive renal fibrosis in murine polycystic kidney disease: an immunohistochemical observation. Kidney Int. 2000; 58: 587-97.

8. Carlisle RE, Heffernan A, Brimble E et al. TDAG51 mediates epithelial-to-mesenchymal transition in human proximal tubular epithelium. Am J Physiol Renal Physiol. 2012; 303: F467-81.

9. Liu X, Hong Q, Wang Z, Yu Y, Zou X, Xu L. Transforming growth factor-beta-sphingosine kinase 1/S1P signaling upregulates microRNA-21 to promote fibrosis in renal tubular epithelial cells. Exp Biol Med (Maywood). 2016; 241: 265-72.

10. Leask A, Abraham D|. TGF-beta signaling and the fibrotic response. Faseb j. 2004; 18: 816-27.

11. Yang J, Liu Y. Dissection of key events in tubular epithelial to myofibroblast transition and its implications in renal interstitial fibrosis. Am / Pathol. 2001; 159: 1465-75.

12. Zhang HY, Phan SH. Inhibition of myofibroblast apoptosis by transforming growth factor beta(1). Am / Respir Cell Mol Biol. 1999; 21: 658-65.

13. Liu Y. New insights into epithelial-mesenchymal transition in kidney fibrosis. J Am Soc Nephrol. 2010; 21: 212-22.

14. Sarhan NR, Omar NM. An immunohistochemical and ultrastructura analysis of the retina in tadalafil (Cialis) treated rats. Acta Histochem. 2018.

15. Socala K, Nieoczym D, Pierog $M$ et al. Effect of Tadalafil on Seizure
Threshold and Activity of Antiepileptic Drugs in Three Acute Seizure Tests in Mice. Neurotox Res. 2018.

16. Guzeloglu M, Yalcinkaya F, Atmaca S et al. The beneficial effects of tadalafil on renal ischemia-reperfusion injury in rats. Urol Int. 2011; 86: 197-203.

17. Girshovich A, Vinsonneau C, Perez | et al. Ureteral obstruction promotes proliferation and differentiation of the renal urothelium into a bladder-like phenotype. Kidney Int. 2012; 82: 428-35.

18. Benli E, Ayyildiz SN, Cirrik S et al. The effect of tadalafil therapy on kidney damage caused by sepsis in a polymicrobial septic model induced in rats: a biochemical and histopathological study. Int Braz / Urol. 2017; 43: 345-55.

19. Juan YS, Chuang SM, Long CY et al. Protein kinase $C$ inhibitor prevents renal apoptotic and fibrotic changes in response to partial ureteric obstruction. BJU Int. 2012; 110: 283-92.

20. Zhang QF. Ulinastatin inhibits renal tubular epithelial apoptosis and interstitial fibrosis in rats with unilateral ureteral obstruction. Mol Med Rep. 2017; 16: 8916-22

21. Zhao J, Wang L, Cao A, Jiang M, Chen X, Peng W. Renal Tubulointerstitial Fibrosis: A Review in Animal Models. Journal of Integrative Nephrology and Andrology. 2015; 2: 75-80.

22. Chevalier RL, Thornhill BA, Forbes MS, Kiley SC. Mechanisms of rena injury and progression of renal disease in congenital obstructive nephropathy. Pediatr Nephrol. 2010; 25: 687-97.

23. Hanna MK. Ureteral Structure and Ultrastructure. Part V. The Dysplastic Ureter. The Journal of Urology. 1979; 122: 796-8.

24. Dey N, Ghosh-Choudhury N, Kasinath BS, Choudhury GG. TGF $\beta$-Stimulated MicroRNA-21 Utilizes PTEN to Orchestrate AKT/mTORC1 Signaling for Mesangial Cell Hypertrophy and Matrix Expansion. PLOS ONE. 2012; 7 : e42316.

25. Sesti C, Florio V, Johnson EG, Kloner RA. The phosphodiesterase-5 inhibitor tadalafil reduces myocardial infarct size. Int / Impot Res. 2007; 19: 55-61.

26. Saenz de Tejada I, Anglin G, Knight IR, Emmick JT. Effects of tadalafil on erectile dysfunction in men with diabetes. Diabetes Care. 2002; 25: 2159-64.

27. Emmick IT, Stuewe SR, Mitchell M. Overview of the cardiovascular effects of tadalafil. European Heart journal Supplements. 2002; 4: H32-H47.

28. Kloner RA, Mitchell M, Emmick JT. Cardiovascular effects of tadalafil in patients on common antihypertensive therapies. Am / Cardiol. 2003; 92 $47 \mathrm{~m}-57 \mathrm{~m}$ 